\title{
EFFECTS OF FUNGICIDES AND RHIZOBUIM INOCULATION ON THE PHYSICAL PROPERTIES OF FABA BEAN (Vicia faba L.) SEEDS \\ Ahmed, T. H. M. ${ }^{*}$ and E. A. E. Elsheikh ${ }^{* *}$ \\ * Faculty of Science an Technology, Shendi University. \\ ** Faculty of Agriculture, Khartoum University. \\ = Corresponding author : tagelsir4m@gmail.com
}

\begin{abstract}
Two field experiments were carried out in two different seasons to study the effects of Fungicide seed dressing and Rhizobium inoculation on the physical properties of Vicia faba L. seeds. Two fungicides (Captan and Fernasan-D) at different concentrations $0,2,4$ and $6 \mathrm{~g} / \mathrm{kg}$ faba bean seeds in the first season and 8 and $10 \mathrm{~g} / \mathrm{kg}$ faba bean seeds in the second season were used.

Three methods of inoculation with Rhizobium leguminosarom bv. viceae strain TAL 1397 were carried out viz: inoculation immediately after or before fungicide seed dressing or inoculation at the seedling stage. Compared to uninoculated plants, inoculation by both methods significantly $(P \leq 0.05)$ increased 100 -seed weight, significantly $(P \leq 0.05)$ decreased total defects percentage and cookability. No effects were observed on either soakability and hydration coefficient. No differences were detected between inoculation after or before seed dressing in all parameters and only inoculation with fungicidal seed dressing was used in the second season. Fungicide seed dressing significantly $(p \leq 0.05)$ affected 100 - seed weight and cookabilty depending on the fungicide toxicity and concentration, the total defect percentage was significantly $(\mathrm{P} \leq 0.05)$ decreased and resulted in a lower hydration coefficient. Captan was found to be more toxic resulting in more effects than Fernasan- D.
\end{abstract}

\section{INTRODUCTION}

Leguminous crops are important source of protein for human and animals. They fix atmospheric nitrogen through their symbiosis with Rhizobium spp. Faba bean (Vicia faba L.) is one of the major legumes grown throughout the world. In Sudan the faba bean is grown in the Northern and River Nile States mainly for human consumption. The seeds used as an essential diet due to the high lysine content of the seeds (Haciseferougullari, et al.,2003).

The quality and nutritional value of the seeds were indicated by their physical and chemical properties. Many factors were found to affect seeds quality, environmental conditions and cultural practices (Elsheikh and Elzidany, 1997). Rhizobium inoculation was found to improve the seeds physical properties, increased shoot, root, and nodules dry weight, nodules number per plant as well as yield and yield component (Mohamed Ahmed and Abdalla,2004).Root rot and wilt diseases of faba bean were common wherever the crop is grown. The problem of poor stand has been always associated with these diseases. Fungicidal seed dressing is being increasingly used in agriculture to control these diseases. They may exert a deleterious influence upon non-targeted soil microorganism and associated biotic processes (Chauhan et al., 1994). Problems arise when inoculants are used in conjunction with fungicidal seed dressing has been reported (Ghosh, 
1995). When chemically treated seeds were inoculated with Rhizobium, the later may be adversely affected by these chemicals. The effects of fungicides on Rhizobium spp depend on the fungicide type, concentration and the rhizobial strain itself. Medicago sativa seeds and above ground parts were drastically reduced following Thiram application (Strezelec, 1997). The negative effects of fungicidal seed dressing can be overcome by seedling inoculation in the furrow or by the use of granular inoculation.

The objectives of this investigation was to study the effect of fungicidal seed dressing with different concentrations and different methods of rhizobial inoculation on the physical properties of faba bean seeds.

\section{MATERIALS AND METHODS}

\section{Seeds, Fungicides, and Rhizobium strain:}

Faba bean variety (Agabat) seeds were collected from the local market. Captan and Fernasan-D fungicides were supplied by the crop Protection Department, Ministry of Agriculture and Forestry, Khartoum North, Sudan. Rhizobium leguminosarum bv. viceae strain TAL 1397 was supplied by Environment and National Resources Research Inistitute,Sudan.

\section{Field experiments}

Two field experiments were carried out at the Demonstration farm of the Faculty of Agriculture. Shambat, University of Khartoum (latitude 15 40 $\mathrm{N}$, longitude $32^{\circ} 32 \mathrm{E}^{\prime}$ ) during two cropping seasons. A complete randomized block design with 3 replicates was adopted.

\section{Treatments}

The treatments were a factorial combination of 2 fungicides, (Captan and Fernasan-D), fungicide concentrations: $0,2,4$ and $6 \mathrm{gm} / \mathrm{kg}$ seeds in the first season and $0,2,4$ and 6 in the first season and up to 8 and $10 \mathrm{gm} / \mathrm{kg}$ seeds in the second season and Rizobium Leguminosarium bv. viceae strain TAL 1397.The Rizobium strain used for inoculation in one of the following ways :

1. Control: uninoculated seeds

2. Inoculation immediately before fungicidal seed dressing.

3. Inoculation immediately after fungicidal seed dressing.

4. Seedling inoculation, 15 days after sowing.

In the first season where as in the second season only three treatments were carried out.

1.control, uninoculated seeds.

2. Inoculation at the same time of fungicidal seed dressing

3. Seedling inoculation, 15 days after sowing.

In both experiments, the land was prepared by deep ploughing, harrowing and leveling. Then the area was ridged $(80 \mathrm{~cm}$ between ridges) and divided into $4 \times 4 \mathrm{~m}$ plots. Hole were made with $20 \mathrm{~cm}$ spacing in one side of the ridges. Five seeds were placed per hole. Plots were immediately irrigated after sowing and then at 10 days intervals. At the seedling stage, the plants were thinned to 3 plants/hole.

At maturity, seeds from each plot were collected, cleaned and freed from dirt, stones and other extraneous grains or dirt. The following parameters were measured: 
100 - seeds weight:

From each sample, 100-seeds were counted randomly in triplicate and the weight was recorded.

Cookability Test:

Twenty grams of beans were processed in $200 \mathrm{ml}$ of tap water in a Labconco apparatus at $110 \circ \mathrm{c}$ for $30 \mathrm{~min}$. The samples were reweighed after processing. Cookability was calculated as follows:

Cookability $\%=$ Weight after processing - Initial weight $(20 \mathrm{gm}) \times 100$ Initial weight $(20 \mathrm{gm})$

\section{Non - Soakers and Hydration Coefficient:}

For each treatment, 100-seeds were selected at random and soaked in tap water at a ratio of 1 part to 4 parts of water for 16 hours. The percentage of non-Soakers in each sample was calculated after sorting and weighing of non - soaker seeds. The non - soakers percentage was calculated as follows:

Non soakers \% = Weight of Non soakers $\times 100$ Initial weight

The hydration coefficient percentage was calculated as follows:.

HydrationCoefficient $\%=$

Weight of soaked beans

Initial weight

\section{Total defects:}

Total defects is a term for seeds which have abnormalities such as being non- soakers, broken or physically damaged failure to reach maturity and/or being very small in size . the total defect percentage was calculated as follows:

Total defect $\%=$ Other defect $\%+$ Non- soaker $\%$

Other defects $\%=\frac{\text { Weight of defect }}{\text { Weight before soaking }} \times 100$

All the above calculations were done according to AOAC (2000) methods. Statistical analysis:

Each sample was analyzed in triplicate and the figures were then averaged. Data were assessed by analysis of variance (ANOVA) and the significance was accepted at $p \leq 0.05$.

\section{RESULTS AND DISCUSSION}

\section{Effect of treatments on $\mathbf{1 0 0}$ - seeds weight :}

As shown in Table (1), Rhizobium inoculation, whether, seed coating or seedling inoculation by strain TAL 1397 significantly $(p \leq 0.05)$ increased 100seeds weight over the un inoculated control plants in the two seasons. . Inoculation at the seedling stage resulted in a higher weight compared to 
seed inoculation. Fungicide seed dressing significantly $(p \leq 0.05)$ decreased 100 -seeds weight in both seasons. Increasing the concentration of both fungicides significantly $(p \leq 0.05)$ reduced the 100-seed weight. Captan resulted in higher seed weight compared to Fernasan-D.

The increase in faba bean 100- seed weight could be attributed to the increase in the amount of nitrogen fixed per plant. The results obtained were in agreement with the findings of Ahmed, 1998 and ElSheikh and ElZidany, 1997 who observed the increase of 100-seeds weight in faba bean following rhizobial application. Fungicidal seed dressing significantly $(p \leq 0.05)$ decreased 100-seeds weight with varying degrees depending on the fungicide toxicity. Captan was found to be more toxic to R.leguminosarum bv. Viceae train TAL 1397 than Frenasan-D and hence resulted in lower 100seeds weight. As fungicide toxicity, fungicide concentration also affected 100 seeds weight, the weight decreased with increasing fungicide concentration above the field recommended rate. The reduction in 100-seeds weight in faba bean (after fungicidal application) was observed by Hussein et al., (1991). This reduction in faba bean 100 -seeds weight could be attributed to the negative results of the fungicides on the survival of nodulating bacteria on the seeds and consequently its symbiosis with faba bean and the amount of nitrogen fixed by the plant.

Table (1): Effect of fungicide treatment and Rhizobium inoculation on 100 -seeds weight (g) and Total defects (\%) (first season).

\begin{tabular}{|c|c|c|c|c|c|}
\hline \multirow{2}{*}{$\begin{array}{l}\text { Concentration } \\
\text { g/kg seed }\end{array}$} & \multirow{2}{*}{$\begin{array}{l}\text { Rhizobium } \\
\text { inoculation }\end{array}$} & \multicolumn{2}{|c|}{ 100-seeds weight(g) } & \multicolumn{2}{|c|}{ Total defects (\%) } \\
\hline & & Fernasan-D & Captan & Fernasan-D & Captan \\
\hline \multirow[t]{4}{*}{0} & R0 & 45.19 & 44.98 & 20.77 & 21.50 \\
\hline & $\mathrm{R} 1$ & 46.04 & 43.08 & 18.80 & 21.43 \\
\hline & $\mathrm{R} 2$ & 46.97 & 45.46 & 20.50 & 21.43 \\
\hline & R3 & 47.58 & 44.82 & 21.00 & 21.10 \\
\hline \multirow[t]{4}{*}{2} & R0 & 45.68 & 44.15 & 21.30 & 21.90 \\
\hline & $\mathrm{R} 1$ & 46.45 & 46.58 & 17.70 & 20.83 \\
\hline & $\mathrm{R} 2$ & 46.89 & 41.96 & 17.90 & 20.27 \\
\hline & R3 & 48.00 & 42.58 & 18.83 & 20.67 \\
\hline \multirow[t]{4}{*}{4} & R0 & 43.41 & 45.28 & 18.70 & 20.00 \\
\hline & R1 & 43.89 & 42.60 & 18.10 & 19.33 \\
\hline & $\mathrm{R} 2$ & 46.36 & 41.00 & 18.70 & 17.70 \\
\hline & R3 & 46.00 & 43.00 & 20.00 & 19.57 \\
\hline \multirow[t]{4}{*}{6} & R0 & 40.00 & 44.66 & 21.33 & 20.00 \\
\hline & R1 & 44.97 & 43.62 & 17.43 & 21.17 \\
\hline & $\mathrm{R} 2$ & 45.60 & 46.48 & 21.70 & 18.60 \\
\hline & R3 & 46.21 & 46.55 & 19.47 & 19.40 \\
\hline
\end{tabular}

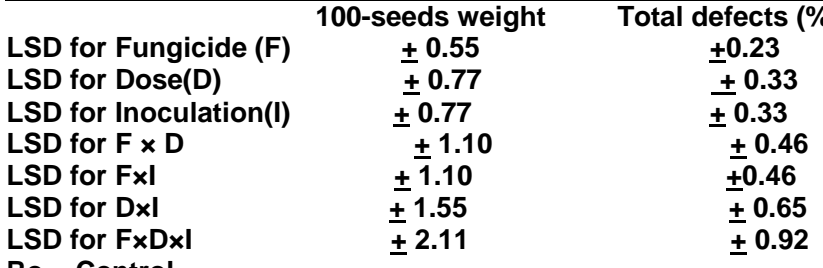

Ro = Control.

R1 = Seed inoculation immediately before seed dressing.

$\mathbf{R 2}=$ Seedling inoculation immediately after seed dressing.

R3 = Seedling inoculation.

Total defects: 
Inoculation by both methods significantly $(p \leq 0.05)$ decreased total defect percentage. The reduction amounts to 7 and $8 \%$ with seed inoculation compared to 5 and $13 \%$ with seedling inoculation in the first and second seasons respectively.

Fungicidal seed dressing significantly $(p \leq 0.05)$ increased total defect percentage (Table 2). Seedling inoculation resulted in lower total defects compared to seed inoculation with fungicidal seed dressing. Fungicidal seed dressing significantly $(p \leq 0.05)$ increased total defects percentage regardless the fungicide concentration or the time of application. The effect of Rhizobium inoculation on the total defects percentage was observed by Elsheikh and Elzidany (1997) who reported $10 \%$ reduction in faba bean seeds.

Generally, the factors that influence total defects percentage, specially hard seeds or non-soakers percentages include the environmental conditions, locality, harvesting, time and variety (Ali et al., 1982).

Table (2): Effect of fungicide treatment and Rhizobium inoculation on 100-seeds weight $(\mathrm{g})$ and Total defects (second season)

\begin{tabular}{|c|c|c|c|c|c|}
\hline \multirow{2}{*}{$\begin{array}{c}\text { Concentration } \\
\text { g/kg seed }\end{array}$} & \multirow{2}{*}{$\begin{array}{l}\text { Rhizobium } \\
\text { inoculation }\end{array}$} & \multicolumn{2}{|c|}{100 -seeds weight(g) } & \multicolumn{2}{|c|}{ Total defects(\%) } \\
\hline & & Fernasan-D & Captan & Fernasan-D & Captan \\
\hline \multirow[t]{3}{*}{0} & R0 & 43.10 & 43.00 & 25.50 & 28.88 \\
\hline & R1 & 43.78 & 44.39 & 21.88 & 24.38 \\
\hline & R2 & 46.93 & 46.72 & 19.10 & 24.01 \\
\hline \multirow[t]{3}{*}{2} & R0 & 44.55 & 44.08 & 23.85 & 26.43 \\
\hline & $\mathrm{R} 1$ & 45.79 & 44.31 & 21.38 & 26.11 \\
\hline & $\mathrm{R} 2$ & 48.97 & 47.64 & 21.72 & 23.55 \\
\hline \multirow[t]{3}{*}{4} & R0 & 43.86 & 43.39 & 23.10 & 28.92 \\
\hline & R1 & 46.00 & 45.76 & 23.27 & 26.88 \\
\hline & $\mathrm{R} 2$ & 49.00 & 48.11 & 24.25 & 21.00 \\
\hline \multirow[t]{3}{*}{6} & R0 & 42.32 & 42.64 & 21.22 & 29.90 \\
\hline & $\mathrm{R} 1$ & 45.13 & 43.53 & 21.00 & 26.15 \\
\hline & $\mathrm{R} 2$ & 47.95 & 46.02 & 19.08 & 24.67 \\
\hline \multirow[t]{3}{*}{8} & R0 & 40.73 & 40.01 & 23.43 & 26.15 \\
\hline & $\mathrm{R} 1$ & 44.07 & 41.26 & 20.57 & 23.67 \\
\hline & R2 & 45.63 & 43.83 & 20.58 & 22.72 \\
\hline \multirow[t]{3}{*}{10} & R0 & 40.37 & 39.50 & 23.10 & 25.83 \\
\hline & R1 & 43.53 & 40.01 & 22.57 & 25.58 \\
\hline & $\mathrm{R} 2$ & 43.97 & 42.88 & 21.87 & 21.55 \\
\hline
\end{tabular}

100-seeds weight(g)

LSD for Fungicide (F)

LSD for Dose(D)

LSD for Inoculation(I)

LSD for $F \times D$

LSD for $F \times I$

LSD for $D \times I$

LSD for $F \times D \times$

RO $=$ Control

R1 = Seed inoculation

R2 = Seedling inoculation $\pm 0.069$

$\pm 0.012$

$\pm 0.083$

$\pm 0.167$

$\pm 0.118$

$\pm 0.204$

$\pm 0.289$

Total defects(\%)

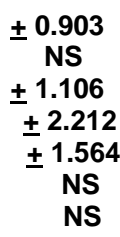

NS

1.106

$+1.564$

NS 
Table (3) : Effect of fungicide treatment and Rhizobium inoculation on Hydration coefficient and Cookability of faba bean seeds (first season)

\begin{tabular}{|c|c|c|c|c|c|}
\hline \multirow{2}{*}{$\begin{array}{l}\text { Concentration } \\
\text { g/kg seed }\end{array}$} & \multirow{2}{*}{$\begin{array}{l}\text { Rhizobium } \\
\text { inoculation }\end{array}$} & \multicolumn{2}{|c|}{ Hydration coefficient (\%) } & \multicolumn{2}{|c|}{ Cookability (\%) } \\
\hline & & Fernasan-D & Captan & Fernasan-D & Captan \\
\hline \multirow[t]{4}{*}{0} & R0 & 140.73 & 140.63 & 20.20 & 20.00 \\
\hline & R1 & 139.10 & 139.53 & 20.43 & 20.10 \\
\hline & $\mathrm{R} 2$ & 140.93 & 139.60 & 20.87 & 18.63 \\
\hline & R3 & 142.03 & 141.30 & 19.37 & 20.70 \\
\hline \multirow[t]{4}{*}{2} & R0 & 141.10 & 140.30 & 21.29 & 19.46 \\
\hline & $\mathrm{R} 1$ & 141.63 & 140.57 & 19.05 & 18.06 \\
\hline & R2 & 140.73 & 140.50 & 19.67 & 19.60 \\
\hline & R3 & 142.10 & 141.53 & 20.95 & 20.12 \\
\hline \multirow[t]{4}{*}{4} & R0 & 141.37 & 140.90 & 20.29 & 19.15 \\
\hline & R1 & 140.57 & 141.07 & 20.66 & 19.87 \\
\hline & R2 & 141.13 & 140.20 & 20.05 & 19.45 \\
\hline & R3 & 141.00 & 141.00 & 20.43 & 21.17 \\
\hline \multirow[t]{4}{*}{6} & R0 & 139.33 & 139.53 & 20.17 & 19.47 \\
\hline & R1 & 139.00 & 139.27 & 20.10 & 19.94 \\
\hline & $\mathrm{R} 2$ & 140.10 & 140.13 & 19.99 & 18.32 \\
\hline & R3 & 140.70 & 140.57 & 19.13 & 19.98 \\
\hline
\end{tabular}

$\begin{array}{lcc} & \text { Hydration coefficient(\%) } & \text { Cookability (\%) } \\ \text { LSD for Fungicide (F) } & \text { NS } & \pm 0.307 \\ \text { LSD for Dose(D) } & \text { NS } & \text { NS } \\ \text { LSD for Inoculation(I) } & \text { NS } & \pm 0.404 \\ \text { LSD for F } \times \text { D } & \text { NS } & \text { NS } \\ \text { LSD for FxI } & \text { NS } & \pm 0.614 \\ \text { LSD for } D \times I & \text { NS } & \pm 0.869 \\ \text { LSD for } F \times D \times I & \text { NS } & \text { NS }\end{array}$

Ro = Control.

R1 = Seed inoculation immediately before seed dressing.

$\mathbf{R} \mathbf{2}$ = Seedling inoculation immediately after seed dressing.

R3 = Seedling inoculation .

\section{Soakability and Hydration coefficient:}

Hydration coefficient is a very valuable factor indicating the good quality of legume seeds for both consumers and processors. It plays a major role in defining the ability of the seeds to absorb water and become ready for processing. Low hydration coefficient indicates that the seeds are not capable of absorbing water efficiently (Ali et al., 1982).Generally, legumes have more than double the initial weight after soaking (Elsheikh and Elzidany, 1997). Rhizobium inoculation and fungicidal treatment did not affect hydration coefficient in the first season (Table 3 ). In the second season, inoculation significantly $(p \leq 0.05)$ increased it. No differences were observed between the two methods of inoculation. Fungicidal seed dressing significantly ( $p \leq$ 0.05 ) reduced the hydration coefficient of the second season harvest. Captan resulted in a lower hydration coefficient than Fernasan $-D$. The differences in the result of the two seasons could be attributed to the time lag between harvesting and analysis as storage conditions may result in decreasing the seeds hydration coefficient (Hussien et al., 1991) In general, hydration coefficient was found to be affected by locality, harvesting time and genotype (Salih and khairi, 1990). 


\section{Cookability:}

As shone in Table (4), in the two seasons, Rhizobium inoculation significantly $(p \leq 0.05)$ increased cookability. No differences were detected between the methods of inoculation compared to uninoculated control plants. Fungicidal treatment significantly $(p \leq 0.05)$ affected cookability with different degrees depending on fungicide toxicity. The phenomenon that make legumes hard to cook is a serious problem. Water absorption by the cotyledon appears to be the key property that affects cookability of legumes. Cookability is significantly associated with hydration coefficient (El Mubarak et al., 1988) and the incidence of hard seed adversely affects cooking quality and, therefore, the market value of the product. Generally, legume cookability is known to be affected by soaking time, type of water, environmental factors, location and time of harvest (El Mubarak et al., 1988).

Table (4): Effect of fungicide treatment and Rhizobium inoculation on Hydration coefficient and Cookability of faba bean seeds (second season)

\begin{tabular}{|c|c|c|c|c|c|}
\hline \multirow{2}{*}{$\begin{array}{l}\text { Concentration } \\
\text { g/kg seed }\end{array}$} & \multirow{2}{*}{$\begin{array}{c}\text { Rhizobium } \\
\text { inoculation }\end{array}$} & \multicolumn{2}{|c|}{ Hydration coefficient(\%) } & \multicolumn{2}{|c|}{ Cookability(\%) } \\
\hline & & Fernasan-D & Captan & Fernasan-D & Captan \\
\hline \multirow[t]{3}{*}{0} & R0 & 163.23 & 150.60 & 23.21 & 25.65 \\
\hline & R1 & 172.27 & 169.90 & 23.56 & 24.75 \\
\hline & R2 & 166.70 & 161.27 & 24.20 & 24.75 \\
\hline \multirow[t]{3}{*}{2} & R0 & 171.10 & 162.10 & 24.98 & 25.58 \\
\hline & R1 & 171.23 & 170.53 & 24.77 & 24.82 \\
\hline & R2 & 175.33 & 165.63 & 25.04 & 24.71 \\
\hline \multirow[t]{3}{*}{4} & R0 & 167.53 & 158.60 & 25.00 & 24.52 \\
\hline & R1 & 167.03 & 173.30 & 24.63 & 24.79 \\
\hline & R2 & 165.67 & 155.80 & 23.66 & 24.02 \\
\hline \multirow[t]{3}{*}{6} & R0 & 161.77 & 165.37 & 25.22 & 24.96 \\
\hline & $\mathrm{R} 1$ & 175.87 & 165.90 & 25.41 & 25.36 \\
\hline & $\mathrm{R} 2$ & 165.47 & 165.77 & 23.39 & 24.32 \\
\hline \multirow[t]{3}{*}{8} & R0 & 168.53 & 162.30 & 25.90 & 24.59 \\
\hline & $\mathrm{R} 1$ & 173.27 & 167.00 & 24.82 & 25.43 \\
\hline & $\mathrm{R} 2$ & 166.17 & 167.00 & 23.74 & 24.48 \\
\hline \multirow[t]{3}{*}{10} & R0 & 169.90 & 154.00 & 24.73 & 24.00 \\
\hline & $\mathrm{R} 1$ & 171.53 & 170.67 & 25.50 & 24.63 \\
\hline & $\mathrm{R} 2$ & 164.90 & 168.83 & 24.33 & 24.94 \\
\hline
\end{tabular}

Hydration coefficient(\%)

$$
\text { Cookability }
$$

LSD for Fungicide (F)

LSD for Dose(D)

LSD for Inoculation(I)

LSD for $F \times D$

LSD for $F \times I$

LSD for $D \times I$

LSD for $F \times D \times I$

$\mathrm{RO}=$ Control

R1 = Seed inoculation

R2 = Seedling inoculation

\pm 3.861
NS
\pm 4.729
NS
NS
NS
NS

NS
NS
0.375
\pm 0.750
NS
NS
NS




\section{REFERENCES}

Ahmed, E.I.A.(1998). Effect of intercropping and inoculation with Rhizobium on growth, Yield and seed quality of faba bean. M.Sc.(Agric.) Thesis, University of Khartoum.

Ali, A.E; Ahmed, G.E .and El Hardallou, E.B.(1982). Faba Beans and their role in diets in Sudan. In: Faba Bean Improvement (Eds. Havtin, G. and webb, C). Martinuss Nijholt Publisher, the Netherland.

Chauhan, U, K, Mahindra, A and Suryanarayana, V. (1994). Influence of soil micro flora in response to application of some pesticides. Journal of Ecotoxicology and Environmental Monitoring 4(2):133-136.

El Mubarak, K.A.A; Salih, F.A; A/Galiel, A. and Gorashi, A.M.(1988) Effect of time harvest on physical and chemical composition, cookability and yield of faba bean .FABIS Newsletter, 20:33-36.

Elsheikh, E.A.E. and Elzidany, A.A.,(1997). Effects of Rhizobium inoculation, organic and chemical fertilizers on yield and physical properties of faba bean seeds. Plant Food for Human Nutrition: 51:137144.

Ghosh, S., (1995). Effects of seeds dressing fungicides on nodulation of groundnut (Arabic hypogea) in vitro. Environment and Ecology. 13(2):369-371.

Haciseferougullari, H.; Gezer, I.;Bahtiyarca,Y. and Menges, H.O. (2003). Determination of some chemical and physical properties of Sakiz bean (Vicia faba L.var. major). Journal of Food Engineering,vol. 60(4): 475479.

Hussein, A.H.A ;Abu-Zeid .N.M and Hassan, M .E.(1991). Effect of Yield Components, nodulation and seed contents of faba bean. Egyptian Journal of Agricultural Research. 69 (3) : 295-708.

Mohamed Ahmed, T.H. and Abdalla,A.S.,(2004). The Response of Some Legumes to Rhizobium Inoculation and the Effect of NPK Fertilizer on Their Symbiosis. Shendi University Journal, Issue NO. 1,62-81.

Salih, F.A and Khairi, N.E. A. (1990). Variation in testa Fraction with some other seed quality attributes of faba bean grown in the new areas in the Sudan. FABIS Newsletter, 27:30-34.

Stezelec, A.(1997). Side effects of Thiram and Carbondazim on Rhizobium and Symbiosis with Leguminous Plants. Ochrona- Roslin.41(1) : 10-12. 
تأثير المبيدات الفطريـة والتلقيح ببكتريـا العقد الجذريـة على الخصـائص الفيزيائيـة لبذور الفول المصري (البلديري)

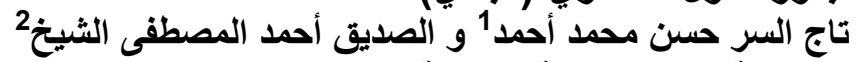

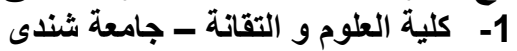

=Corresponding author $:$ tagelsir4m@gmail.com

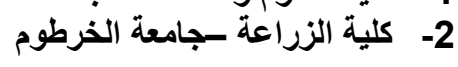

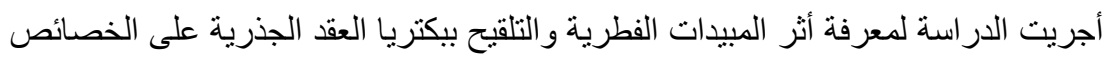

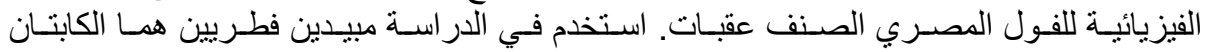

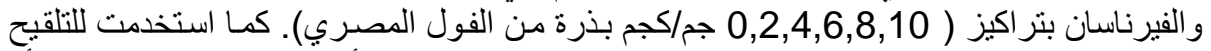

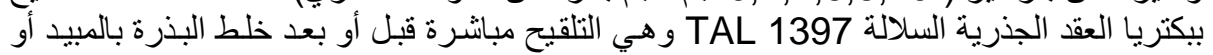
إضافة اللقاح عند ظهور البذادرات.

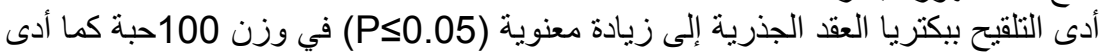

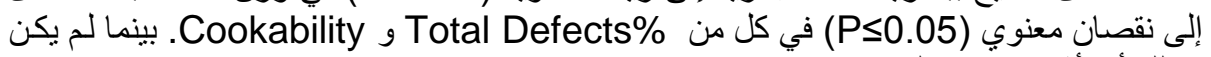

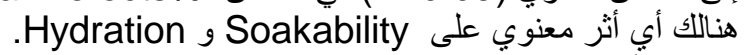

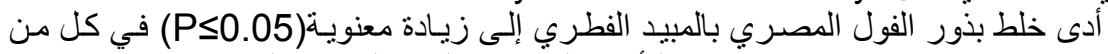

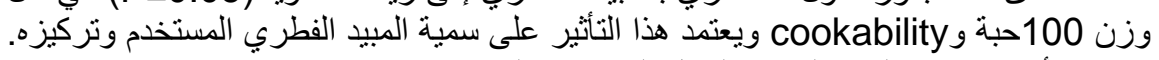

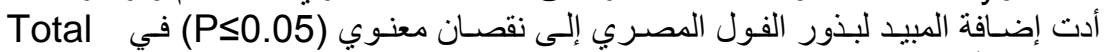

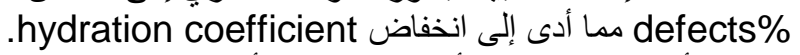

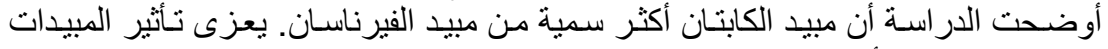

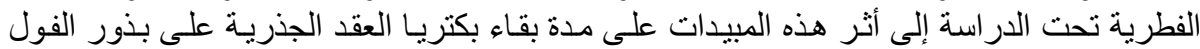

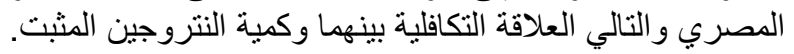

$$
\text { كلية الزراعة - جامعة المنصورة المركى للبحوث }
$$

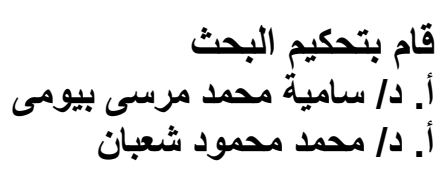

